\title{
Cocaine Cardiomyopathy, Physicians should be aware and focused on Management.
}

\section{Naresh Sen}

Director- Cardiology, BYN Hospital, India

Corresponding author: Naresh Sen, Director- Cardiology, BYN Hospital, India

Received date: October 29, 2019; Accepted date: December 26, 2019; published date: January 02 , 2020

Citation: Sen N. (2020) Cocaine cardiomyopathy, physicians should be aware and focused on management. J Clinical Cardiology and Cardiovascular Interventions, 3(1); DOI:10.31579/2641-0419/024

Copyright: (C) 2020 Naresh Sen. This is an open access article distributed under the Creative Commons Attribution License, which permits unrestricted use, distribution, and reproduction in any medium, provided the original work is properly cited.

\section{Introduction}

More than 14 million people worldwide, mostly within the age range of 15 to 64 years, consume cocaine. Men of 15-35 years represent the majority. Cocaine is a potent sympathomimetic agent associated with the development of possible fatal cardiovascular complications. Hypertension, Dilated cardiomyopathy, Dysrhythmias and Acute myocardial infarction are just some of many cardiovascular effects related to the abuse of cocaine. The management is like other forms of cardiomyopathy; however $\beta$-blockers should be avoided. Non-invasive testing should be performed after several months to re-evaluate the treatment response. Dose-dependent tachycardia, hypertension along with increased arousal is the first physiological response to cocaine use. Performance improvement, attentiveness, sense of positive self-image and euphoria often accompany the cumulative use of cocaine. End-organdamage associated with cocaine can affect almost every organ system. Cocaine results in a gradual addiction due to its vigorous sympathomimetic features with possible destructive cardiovascular effects. Dysrhythmias, acute myocardial infarction, myocarditis, hypertension, endocarditis, hypotensive shock, cerebral vascular accidents and dilated cardiomyopathy are several cardiovascular complications due to cocaine abuse [1]. Cocaine blocks the presynaptic dopamine and catecholamine uptake, resulting in post-synaptic sympathetic stimulation and dopaminergic receptor activation [2]. Peripheral vasoconstriction results in hypertension, tachycardia and an increase in afterload. Arrhythmias are likely to occur due to the altered autonomic action and cardiovascular resistance results in a decreased myocardial blood supply [3]. Negative inotropic events can also occur from cocaine abuse. Hypertrophy of the left ventricle and cardiomyopathy with significant reduction of the ejection fraction has been described in the setting of chronic cocaine consumption. Myocardial hypertrophy is likely to occur secondary to the temporary blood pressure elevation after cocaine use [4]. Smoking and alcohol use exacerbate the cardiotoxic impact of cocaine [5].

\section{Discussion}

Cocaine stimulates the sympathetic nervous system by inhibiting catecholamine reuptake at sympathetic nerve terminals, stimulating central sympathetic outflow, and increasing the sensitivity of adrenergic nerve endings to norepinephrine [7-8]. Cocaine also acts like a class I antiarrhythmic agent (local anesthetic) by blocking sodium and potassium channels, which depresses cardiovascular parameters. [9] Of these 2 primary, opposing actions, enhanced sympathetic activity predominates at low cocaine doses, whereas the local anesthetic actions are more Prominent at higher doses. [8] In addition, cocaine stimulates the release of endothelin-1, a potent vasoconstrictor, from endothelial cells [10] and inhibits nitric oxide production, the principal vasodilator produced by endothelial cells. [11] Cocaine promotes thrombosis by activating platelets, [12-13] increasing platelet aggregation, [12,14] increasing platelet $\alpha$-granule release, $[12,15]$ increasing plasminogen activator inhibitor activity.[16]

Cocaine increases myocardial oxygen demand by increasing both heart rate and blood pressure. $[17,18]$ The influence of cocaine on heart rate and blood pressure is dose dependent and is mediated through $\alpha$-adrenergic stimulation. $[17,18]$ At the same time, cocaine decreases oxygen supply via coronary vasoconstriction. Cocaine-induced coronary vasoconstriction occurs in normal (nondiseased) coronary artery segments but is more pronounced in atherosclerotic segments. [19] Combining cocaine use with cigarette smoking has additive effects on coronary vasoconstriction while markedly increasing the rate-pressure product. Long-term cocaine users demonstrate coronary endothelial dysfunction. [20,21]. Because endothelial dysfunction increases the sensitivity of a vessel to the constrictor effects of catecholamines, [22] it may be particularly detrimental for cocaine users. Even in the absence of epicardial coronary disease, cocaine causes microvascular disease $[23,24]$ and is associated with thrombosis. [25,26]

Cocaine causes systolic and diastolic dysfunction, arrhythmias, and atherosclerosis. Cocaine decreases myocardial contractility and ejection fraction by blocking sodium and potassium channels within the myocardium. [27] Intracoronary infusion of cocaine decreases left ventricular ejection fraction and increases left ventricular end-diastolic pressure and end-systolic volume.[28] Long-term cocaine use is associated with left ventricular hypertrophy and prolonged deceleration time. [29,30] Cocaine prolongs the PR, QRS, and QT intervals. [31,32] Cocaine is associated with coronary atherosclerosis even in young users with relatively few cardiac risk factors. $[33,34]$ Cocaine causes systolic dysfunction in long-term users and with acute intoxication. In a dog model, acute cocaine intoxication caused left ventricular dilation, decreased contractility, and increased end-diastolic pressure. [35] Rabbits demonstrated regional wall motion abnormalities (mostly anteroseptal) associated with decreased left ventricular fractional shortening and increased systolic dimension in response to acute cocaine intoxication. [36] After 2 weeks of abstinence from cocaine, 6 of 84 (7\%) asymptomatic cocaine users (mean age, 36 years) had an ejection fraction <55\%.[37] In 33 cocaine-using patients undergoing coronary angiography (indication: chest pain, 28; congestive heart failure, 4 ), ejection fraction was abnormal in 18 patients $(55 \%)$ and $\leq 30 \%$ in 6 patients (18\%).[33] Moreover, 4 patients had an ejection fraction $<30 \%$ with global hypokinesis. Dilated cardiomyopathy is more common among cocaine users, [34] but a case of left ventricular apical ballooning (Takotsubo cardiomyopathy) has also been described. [38] In a registry including 83 hospitals nationally, stimulant drug use (96\% cocaine, 5\% methamphetamine) was selfreported in 594 of 11258 patients (5.3\%) who presented to the emergency department with acute decompensated heart failure. [39] Patients with stimulant drug use were more likely to have $\geq 3$ hospitalizations within 6 months (28\% versus $11 \%$ ) and had lower ejection fractions (median, $23 \%$ 
versus $40 \%)$.

Acute cocaine intoxication decreases myocardial contractility and ejection fraction [27,28] and increases left ventricular end-diastolic pressure and end-systolic volume. [28] Long-term cocaine use is associated with left ventricular hypertrophy and prolonged deceleration time. [30] The pathophysiology of cocaine-associated cardiomyopathy, however, remains unclear. Of 18 cocaine users undergoing coronary angiography with an ejection fraction $<55 \%, 12$ had coronary artery disease and regional wall motion abnormalities suggesting recent or remote MI; however, 6 did not have coronary artery disease and demonstrated global hypokinesis (4 of 6 with an ejection fraction $<30 \%$ ).[33] Thus, a manifestation of coronary artery disease can explain cocaine-induced ventricular dysfunction in some patients, but cocaine also has a direct toxic effect on cardiac myocytes. Factors contributing to cocaine-induced cardiomyopathy may include the blocking of sodium and potassium channels within the myocardium, alterations in calcium ion handling, [28] myocardial inflammation with necrosis and fibrosis, left ventricular hypertrophy, [29,30] alterations in gene expression, [39] and concomitant alcohol consumption. [33]

Cessation of cocaine is the primary therapeutic goal in cocaine-induced cardiomyopathy. Cocaine-induced heart failure improved dramatically with cessation of cocaine and recurred with resumption of cocaine. [34] As with CACP, medical therapy for cocaine-induced heart failure and cardiomyopathy should follow published guidelines, except all $\beta$-blockers should be avoided in the acute setting. Thereafter, $\beta$-blockers should be considered for each patient individually, after careful risk-benefit assessment, and maybe after cocaine cessation has been documented. Continued cocaine use precludes eligibility for cardiac transplantation.

\section{Summary}

Cocaine is a potent sympathomimetic agent associated with the development of possible fatal cardiovascular complications. Hypertension, Dilated cardiomyopathy, Dysrhythmias and Acute myocardial infarction are just some of many cardiovascular effects related to the abuse of cocaine. The therapy of cocaine-induced cardiomyopathy is similar to the way that other types of cardiomyopathy are managed. Beta-blockers should not be considered initially; benzodiazepine is preferred to counteract the adrenergic effect. In the acute setting the addition of beta-blockers will adversely result in the alpha-adrenergic receptors being unopposed, therefore leading to coronary vasoconstriction, left ventricle wall stress and a hypertensive crisis. As recommended in other types of cardiomyopathy, pharmacological agents such as, diuretics, Angiotensin-Converting-Enzyme Inhibitors, Angiotensin-Receptor Blocker, vasodilators, or digoxin should be initially included. Cessation of cocaine is the primary goal of postdischarge therapy. The use of cocaine should be investigated in patients with cardiovascular disease, especially young patients, because its presence may influence disease diagnosis, management, and therapy. Non-invasive testing should be performed after several months to re-evaluate the treatment response.Cocaine use should be considered if young patients presented with heart failure, mainly without other underlying risk factors. It is important to counsel these patients regarding the deleterious effects of cocaine abuse and the potential reversal of cardiac dysfunction with abstaining from the cocaine use. The unfavorable economic impact and awareness of the possible cardiovascular effects should be considered during the initial evaluation when young adults with heart failure for medical assessment

\section{References}

1. Fraker TD Jr, Madu EC, Mouhaffel AH, Satmary WA. (1995) Cardiovascular complications of cocaine.Chest. 107(5):14261434.

2. Afonso L, Mohammad T, Thatai D. Crack whips the heart: a review of the cardiovascular toxicity of cocaine. Am J Cardiol. 2007;100:1040-1043.
3. Abraham JR, Butany J, Leong S, Luk A, Phillips K, Soor GS. (2009) Cocaine cardiotoxicity a review of the pathophysiology, pathology, and treatment options. Am J Cardiovasc Drugs. 9(3):177-196.

4. Carrillo J, Marmol-Velez A, Martinez S, Restrepo CS, Riascos R, Rojas CA, Vargas D. (2009) Cardiovascular complications of cocaine: imaging findings. Emerg Radiol. 16:11-19.

5. Figueredo VM, Maraj S, Morris DL. (2010) Cocaine and the heart. Clin Cardiol. 33(5):264-269.

6. Figueredo VM. (2011) Chemical cardiomyopathies: the negative effects of medications and nonprescribed drugs on the heart. Am J Med. 124:480-488.

7. Vongpatanasin W, Mansour Y, Chavoshan B, Arbique D, Victor RG. (1999) Cocaine stimulates the human cardiovascular system via a central mechanism action. Circulation. 100: 497-502.

8. Egashira K, Morgan KG, Morgan JP. (1991) Effects of cocaine on excitation-contraction coupling of aortic smooth muscle from the ferret. J Clin Invest. 87: 1322- 1328.

9. Przywara DA, Dambach GE. (1989) Direct actions of cocaine on cardiac cellular electrical activity. Circ Res. 65: 185- 192.

10. Wilbert-Lampen U, Seliger C, Zilker T, Arendt RM. (1998) Cocaine increases the endothelial release of immunoreactive endothelin and its concentrations in human plasma and urine: reversal by coincubation with sigma-receptor antagonists. Circulation. 98: 385-390.

11. Mo W, Singh AK, Arruda JA, Dunea G. (1998) Role of nitric oxide in cocaine-induced acute hypertension. Am $\mathrm{J}$ Hypertens. 11: 708-714.

12. Heesch CM, Wilhelm CR, Ristich J,Adnane J, Bontempo FA, Wa gner WR . (2000) Cocaine activates platelets and increases the formation of circulating platelet containing microaggregates in humans. Heart. 83: 688- 695.

13. Kugelmass AD, Oda A, Monahan K, Cabral C, Ware JA. (1993) Activation of human platelets by cocaine. Circulation. 88: 876-883.

14. Rezkalla SH, Mazza JJ, Kloner RA, Tillema V, Chang SH. (1993) Effects of cocaine on human platelets in healthy subjects. Am J Cardiol. 72: 243- 246.

15. Rinder HM, Ault KA, Jatlow PI, Kosten TR, Smith BR. (1994) Platelet alpha-granule release in cocaine users. Circulation. 90: 1162- 1167.

16. Moliterno DJ, Lange RA, Gerard RD, Willard JE, Lackner C, Hill is LD. (1994) Influence of intranasal cocaine on plasma constituents associated with endogenous thrombosis and thrombolysis. Am J Med. 96: 492- 496.

17. Lange RA, Cigarroa RG, Yancy CW Jr., Willard JE, Popma JJ. et al. (1989) Cocaine-induced coronary-artery vasoconstriction. N Engl J Med. 321: 1557- 1562.

18. Fischman MW, Schuster CR, Resnekov L, Shick JF, Krasnegor N A. et al. (1976) Cardiovascular and subjective effects of intravenous cocaine administration in humans. Arch Gen Psychiatry. 33: 983-989.

19. Flores ED, Lange RA, Cigarroa RG, Hillis L. (1990) Effect of cocaine on coronary artery dimensions in atherosclerotic coronary artery disease: enhanced vasoconstriction at sites of significant stenoses. J Am Coll Cardiol. 16: 74-79.

20. Moliterno DJ, Willard JE, Lange RA, Negus BH, Boehrer JD, Gla mann DB, Landau C, Rossen JD, Winniford MD, Hillis LD. (1994) Coronary-artery vasoconstriction induced by cocaine, cigarette smoking, or both. N Engl J Med. 330: 454-459.

21. Havranek EP, Nademanee K, Grayburn PA, Eichhorn EJ. (1996) Endothelium-dependent vasorelaxation is impaired in cocaine arteriopathy. J Am Coll Cardiol. 28: 1168- 1174.

22. Vita JA, Treasure CB, Fish D, Yeung AC, Vekshtein VI, Ganz P. (1990) Selwyn AP Endothelial dysfunction leads to increased coronary constriction to catecholamines in patients with early atherosclerosis. J Am Coll Cardiol. 15: 158A. 
23. Kelly RF, Sompalli V, Sattar P, Khankari K. (2003) Increased TIMI frame counts in cocaine users: a case for increased microvascular resistance in the absence of epicardial coronary disease or spasm. Clin Cardiol. 26: 319-322.

24. Weber JE, Hollander JE, Murphy SA, Braunwald E, Gibson CM. ( 2002) Quantitative comparison of coronary artery flow and myocardial perfusion in patients with acute myocardial infarction in the presence and absence of recent cocaine use. J Thromb Thrombolysis. 14: 239- 245.

25. Tazelaar HD, Karch SB, Stephens BG, Billingham ME. (1987) Cocaine and the heart.Hum Pathol. 18: 195- 199.

26. Virmani R, Robinowitz M, Smialek JE, Smyth DF. (1988) Cardiovascular effects of cocaine: an autopsy study of 40 patients. Am Heart J. 115: 1068- 1076.

27. Hale SL, Alker KJ, Rezkalla SH, Eisenhauer AC, Kloner RA. (19 91) Nifedipine protects the heart from the acute deleterious effects of cocaine if administered before but not after cocaine. Circulation. 83: 1437- 1443.

28. Pitts WR, Vongpatanasin W, Cigarroa JE, Hillis LD, Lange RA. ( 1998) Effects of the intracoronary infusion of cocaine on left ventricular systolic and diastolic function in humans. Circulation. 97: 1270- 1273.

29. Brickner ME, Willard JE, Eichhorn EJ, Black J, Grayburn PA. (19 91) Left ventricular hypertrophy associated with chronic cocaine abuse. Circulation. 84: 1130-1135.

30. Tong W, Lima JA, Meng Q, Flynn E, Lai S. (2004) Long-term cocaine use is related to cardiac diastolic dysfunction in an AfricanAmerican population in Baltimore, Maryland. Int $\mathbf{J}$ Cardiol. 97: 25-28.
31. Hale SL, Lehmann MH, Kloner RA. (1989) Electrocardiographic abnormalities after acute administration of cocaine in the rat. Am J Cardiol. 63: 1529- 1530.

32. Aslibekyan S, Levitan EB, Mittleman M. (2008) Prevalent cocaine use and myocardial infarction. Am J Cardiol. 102: 966-969.

33. Om A, Warner M, Sabri N, Cecich L, Vetrovec G. (1992) Frequency of coronary artery disease and left ventricle dysfunction in cocaine users. Am J Cardiol. 69:1549- 1552.

34. Willens HJ, Chakko SC, Kessler KM. (1994) Cardiovascular manifestations of cocaine abuse: a case of recurrent dilated cardiomyopathy. Chest. 106: 594- 600 .

35. Hale SL, Alker KJ, Rezkalla S, Figures G, Kloner RA. (1989) Adverse effects of cocaine on cardiovascular dynamics, myocardial blood flow, and coronary artery diameter in an experimental model. Am Heart J. 118: 927-933.

36. Gardin JM, Wong N, Alker K, Hale SL, Paynter J. et al. (1994) Acute cocaine administration induces ventricular regional wall motion and ultrastructural abnormalities in an anesthetized rabbit model. Am Heart J. 128: 1117- 1129.

37. Bertolet BD, Freund G, Martin CA, Perchalski DL, Williams CM, Pepine CJ. (1990) Unrecognized left ventricular dysfunction in an apparently healthy cocaine abuse population. Clin Cardiol. 13: 323-328.

38. Arora S,Alfayoumi F, Srinivasan V. (2006) Transient left ventricular apical ballooning after cocaine use: is catecholamine cardiotoxicity the pathologic link?Mayo Clin Proc. 81: 829-832.

39. Diercks DB, Fonarow GC, Kirk JD. (2008) Illicit stimulant use in a United States heart failure population presenting to the emergency department (from the Acute Decompensated Heart Failure National Registry Emergency Module). Am J Cardiol. 102: 1216- 1219.
This work is licensed under Creative Commons Attribution 4.0 License
Ready to submit your research? Choose Auctores and benefit from:

* fast, convenient online submission

* rigorous peer review by experienced research in your field

* rapid publication on acceptance

* authors retain copyrights

* unique DOI for all articles

* immediate, unrestricted online access

At Auctores, research is always in progress.

Learn more www.auctoresonline.org/journals/clinical-cardiology-andcardiovascular-interventions 